\title{
Annual energy consumption evaluation of naturally ventilated double skin façade in hot summer and cold winter zone
}

\author{
Youming Chen ${ }^{1,2}$, Cong $\mathrm{Li}^{1,2}$, Yanjin Wang ${ }^{1,2}$ \\ ${ }^{1}$ College of Civil Engineering, Hunan University, Changsha, Hunan 410082, China \\ ${ }^{2}$ Key Laboratory of Building Safety and Energy Efficiency of the Ministry of Education, Hunan \\ University, Changsha, Hunan 410082, China
}

\begin{abstract}
Double skin façade (DSF) is a new fabric increasingly used in hot summer and cold winter (HSCW) zone in China. Architecture designers and users have concerned its energy performance. Former scholars have simulated the thermal performance of DSF with different methods, such as CFD and airflow network methods. However, to evaluate the annual energy consumption, a method with good speed and accuracy is needed. In this paper, an improved zonal model validated by experimental data is used to simulate the energy performance of the naturally ventilated DSF for two constructions in HSCW zone. The results show that the naturally ventilated DSF with interior double glass has better thermal and energy performance. Meanwhile, heat gains of several most common-used fabrics in six typical cities of HSCW zone are calculated. The results show that the annual energy demand differences between the DSF and the most thermally insulated fabric (aerated concrete wall with external XPS insulation layer + double glazing window) are generally within $10 \%$ except the north orientation. Considering some advantages over the traditional fabrics, such as indoor lighting, visual comfort, the naturally ventilated DSF has good adaptability in $\mathrm{HSCW}$ zone in China.
\end{abstract}

\section{Introduction}

Comparing with traditional windows, DSF has some advantages, such as ventilation, day lighting control, noise isolation, and so on. The energy performance of DSF is relevant to many influence factors including the climate, orientation, operate mode of ventilation and shading devices, window-wall ratio, configuration, and so on (Ali et al., 2016; Francesco, et al., 2016). The designers and users are worried about overheating and heat loss risk of DSF.

Studies have been made to compare the energy consumption of DSF and single glass facade under different climate conditions (Marí, et al., 2012; N. Hashemi, et al., 2010; E. Sanchez, et al., 2016). The results show that DSF can significantly reduce heating loss in winter and heat gain in summer. In the air cavity of DSF, shading devices is common installed to help adjust the lighting and solar gain (L.G, et al., 2017). Studies made by G. Baldinelli (2009) and Jinqing Peng et al. $(2013 ; 2016)$ show that energy consumption of DSF with movable venetian blinds is less than traditional facades. Many studies show that thermal and energy performance of the DSF can be improved by ventilation in air cavity (Yu-Min, et al., 2011; Wonjun, et al., 2012).

Hot summer and cold winter (HSCW) zone is one of the typical climate zones in China. In HSCW zone, the average temperature of the coldest and the hottest month are $0-10^{\circ} \mathrm{C}$ and $25-30^{\circ} \mathrm{C}$. The energy consumption due to the overheating and heat loss problems in cooling and heating seasons is highly concerned. Hence, it is necessary to calculate the annual energy consumption of the DSF and compare it with the local energy saving fabrics, which can evaluate the energy performance and applicability of the DSF in this climate zone.

Some methods can be used to simulate the thermal performance of the DSF, such as lumped method (Marta, et al., 2016), analytical method (Hossein, et al., 2012), airflow network method (Fallahi, et al., 2010; Hashemi, et al., 2010) control volume method (Alvaro, et al., 2013), and CFD method (Alessandro, et al., 2017; Yilin, et al., 2017; Ahmed, et al., 2015). However, these methods are not suitable for the annual energy consumption evaluation of the DSF due to the slow computing speed and the massive computing resources and inaccuracy. To solve this problem in this study, an improved zonal method (Yangjin Wang, Youming Chen, et al., 2019) is used to model the thermal performance of the DSF dynamically, and it is integrated with optical model (Yanjin Wang \& Youming Chen, 2016) and airflow model to simulate the naturally ventilated DSF with venetian blinds. The model is validated by experiments. In this study, the annual energy demand of the naturally ventilated DSF is calculated using the integrated model and the meteorological data of six typical cities in HSCW zone. The energy performance and applicability of the naturally ventilated DSF is evaluated through comparing with several most commonly used fabrics in this climate zone.

\section{DSF configurations}

The naturally ventilated DSF is a multi-glazing layer system which consists of two glazing layers (a single glass and a double glass), an air cavity between the two glazing layers and a venetian blind fixed in the cavity. 


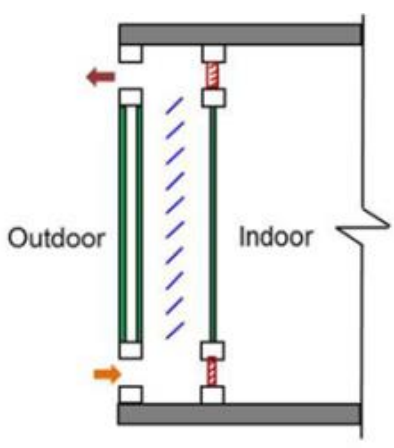

Figure 1:Configurations of DSF

To get the best performance of naturally ventilated DSF, the air inlet and outlet on outer surface should open in summer and shut in winter; the venetian blinds should install in summer and remove in winter.

\section{Mathematical model and validation}

Wang and Chen have developed an optical model and an airflow model to calculate solar radiation and the complex airflow in air cavity of naturally ventilated DSF (Yangjin Wang, Youming Chen, et al., 2019; Yanjin Wang \& Youming Chen, 2016). The whole DSF can be simulated by the improved zonal model integrated with optical model and airflow model (Yanjin Wang \& Youming Chen, 2016). The establishment of heat balance equations refer to the equations given in (Yangjin Wang, Youming Chen, et al., 2016). The improved zonal model of naturally ventilated DSF with venetian blinds is validated by experimental results (Yanjin Wang \& Youming Chen, 2016). The results show that simulated results have a very good agreement with measured results. This model can evaluate the annual energy performance of naturally ventilated DSF with venetian blinds accurately and quickly.

\section{Evaluation and results}

In hot summer and cold winter zone of China, the heating season is from December 1 to February 28, and the cooling season is from June 15 to September 15 in HSCW zone. The heat gains through the DSF in cooling and heating seasons are calculated and compared against the commonly used fabrics in $\mathrm{HSCW}$ zone. Heat gains through naturally ventilated DSF are calculated using the validated mathematical model. The heat gains through the other fabrics are calculated by the harmonic response method (Fernando, et al.,2012) for the opaque part, and the transparent part is simulated by the method in (Yanjin Wang \& Youming Chen, 2016). All calculated fabrics are listed in Table 1. In these fabrics, Case A is the most commonly used fabric, and Case D is the most thermally insulated one.

The window-wall ratio (WWR) of each fabric listed in Table 1 is specified for in HSCW zone. The parameters of the construction and materials for the fabrics are listed in Table 2 (GB 50736,2012).

Table 1:The calculated fabrics and their window-wall ratio $(W W R)$.

\begin{tabular}{|l|l|l|}
\hline Nr. & Fabrics & WWR \\
\hline
\end{tabular}

\begin{tabular}{|c|c|c|}
\hline $\begin{array}{c}\text { Case } \\
\text { A }\end{array}$ & $\begin{array}{c}\text { Solid brick wall + double glazing } \\
\text { window }(5 \mathrm{~mm}+12 \mathrm{~A}+5 \mathrm{~mm})\end{array}$ & 0.3 \\
\hline $\begin{array}{c}\text { Case } \\
\text { B }\end{array}$ & $\begin{array}{c}\text { Perforated brick wall with external EPS } \\
\text { insulation layer + double glazing window } \\
(5 \mathrm{~mm}+12 \mathrm{~A}+5 \mathrm{~mm})\end{array}$ & 0.3 \\
\hline $\begin{array}{c}\text { Case } \\
\text { C }\end{array}$ & $\begin{array}{c}\text { Reinforced concrete wall with external } \\
\text { EPS insulation layer + double glazing } \\
\text { window }(5 \mathrm{~mm}+12 \mathrm{~A}+5 \mathrm{~mm})\end{array}$ & 0.3 \\
\hline $\begin{array}{c}\text { Case } \\
\text { D }\end{array}$ & $\begin{array}{c}\text { Aerated concrete wall with external XPS } \\
\text { insulation layer + double glazing window } \\
(5 \mathrm{~mm}+12 \mathrm{~A}+5 \mathrm{~mm})\end{array}$ & 0.3 \\
\hline $\begin{array}{c}\text { Case } \\
\text { E }\end{array}$ & $\begin{array}{c}\text { Single glazing façade (double glass: } \\
6 \mathrm{~mm}+12 \mathrm{~A}+6 \mathrm{~mm}) \text { with external venetian } \\
\text { blind }\end{array}$ & 0.7 \\
\hline $\begin{array}{c}\text { Case } \\
\text { F }\end{array}$ & $\begin{array}{c}\text { Naturally ventilated double skin façade } \\
(6 \mathrm{~mm} \text { glass+(6mm+12A+6mm) double } \\
\text { glass })\end{array}$ & 0.7 \\
\hline
\end{tabular}

Table 2: Parameters for the construction and materials

\begin{tabular}{|c|c|c|}
\hline Material & $\begin{array}{c}\text { Thickness } \\
(\mathbf{m m})\end{array}$ & $\begin{array}{c}\text { Thermal } \\
\text { conductivity } \\
(\mathbf{W} /(\mathbf{m} \cdot \mathbf{K}))\end{array}$ \\
\hline Solid brick & 240 & 0.7 \\
\hline Perforated brick & 240 & 0.64 \\
\hline Reinforced concrete & 200 & 1.74 \\
\hline $\begin{array}{c}\text { Aerated concrete } \\
\text { bloc }\end{array}$ & 200 & 0.22 \\
\hline Cement mortar & 20 & 0.93 \\
\hline ESP & 40 & 0.042 \\
\hline XPS & 40 & 0.03 \\
\hline Clear glass & $5 / 6$ & 0.76 \\
\hline
\end{tabular}

The heat gain and loss through these fabrics in cooling and heating seasons in six typical cities in HSCW zone are calculated, which are Shanghai, Nanjing, Changsha, Wuhan, Chongqing and Chengdu. Annual energy demand of a fabric is the heat gain in cooling season plus its heat loss in heating season. In the calculations, the slat angle of the venetian blind is $45^{\circ}$ in Case $\mathrm{E}$ and Case F in cooling season. While, in heating season, the venetian blinds of Case $\mathrm{E}$ and Case $\mathrm{F}$ are removed, and the vents of Case $\mathrm{F}$ are closed. The indoor air temperatures are set to $26^{\circ} \mathrm{C}$ and $18^{\circ} \mathrm{C}$ in cooling and heating season, respectively.

\section{Heat gain in cooling season}

Figure 2 shows the heat gains for Case A to $\mathrm{F}$ in six cities in cooling season. It can be found that the heat gains of Case $\mathrm{A}$ and $\mathrm{E}$ are higher than the other fabrics, and that of the three thermally insulated walls (Case B, C and D) are very close. The heat gain of single glazing facade (Case E) is the maximum one due to its poor thermal performance. 


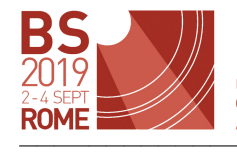

16th IBPSA
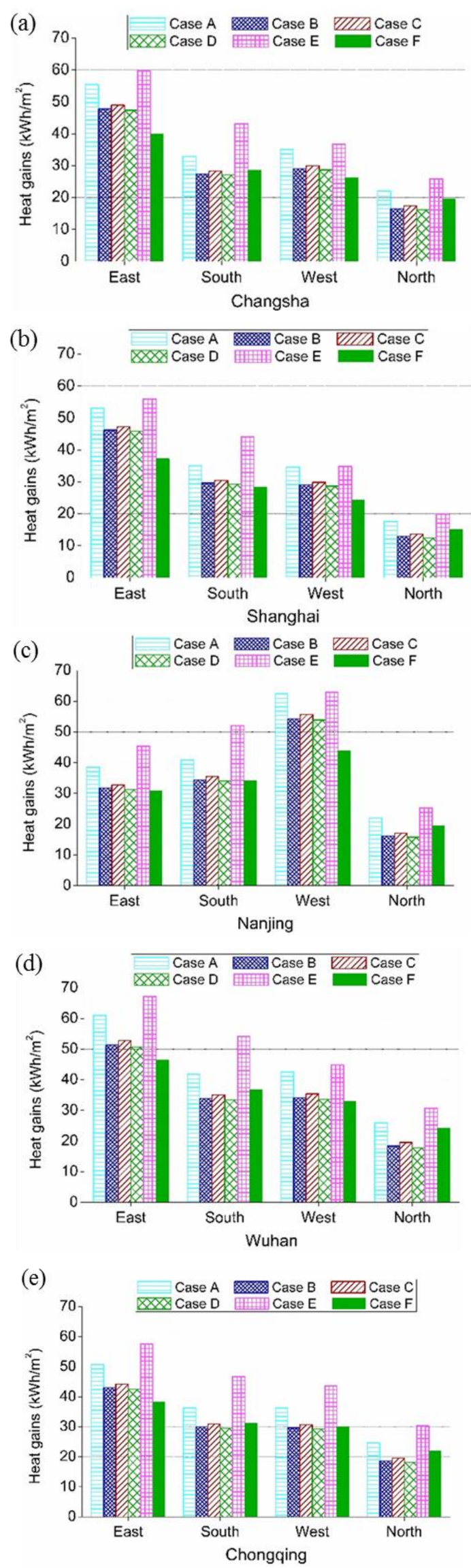

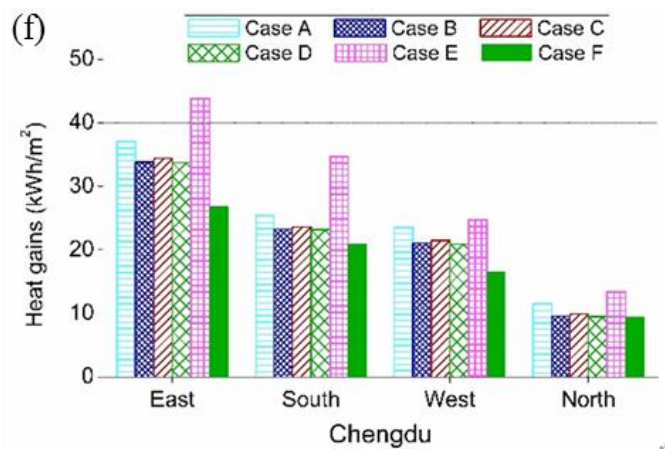

Figure 2: Heat gains through all fabrics in all orientations in cooling season: (a) Changsha, (b) Shanghai, (c) Nanjing,

(d) Wuhan, (e) Chongqing, $(f)$ Chengdu

Heat gains through the DSF (Case F) compared with the most commonly used fabric (Case A) in HSCW zone is shown in Table 3. Heat gain of the DSF compared to Case A in the east, south, west and north orientations reaches at least to $25.05 \%, 13.85 \%, 20.8 \%$, and $7.07 \%$. Meanwhile, Reduced heat gain of the DSF (Case F) compared to the most thermally insulated fabric (Case D) is shown in Table 4. The comparisons indicate that the DSF (Case F) has better energy efficiency than Case D in the east and west orientations. However, for the south and north orientations, the energy efficiency of Case F is slightly inferior to Case D. It can be found that in most of the cities, the heat gains through the DSF is less than Case A-E.

Table 3:Reduced heat gain (\%) of the DSF (Case F) compared to the most commonly used fabric (Case A) in cooling season

\begin{tabular}{|c|c|c|c|c|}
\hline $\begin{array}{c}\text { Orientation } \\
\text { cities }\end{array}$ & East & South & West & North \\
\hline Changsha & $38.28 \%$ & $15.25 \%$ & $33.38 \%$ & $13.06 \%$ \\
\hline Shanghai & $42.63 \%$ & $23.47 \%$ & $42.36 \%$ & $16.81 \%$ \\
\hline Nanjing & $25.05 \%$ & $19.91 \%$ & $42.44 \%$ & $13.50 \%$ \\
\hline Wuhan & $31.72 \%$ & $13.85 \%$ & $28.91 \%$ & $7.07 \%$ \\
\hline Chongqing & $32.84 \%$ & $16.39 \%$ & $20.8 \%$ & $11.64 \%$ \\
\hline Chengdu & $38.28 \%$ & $21.56 \%$ & $43.16 \%$ & $22.56 \%$ \\
\hline
\end{tabular}

Table 4:Reduced heat gain (\%) of the DSF (Case F) compared to the most thermally insulated fabric (Case D) in cooling season

\begin{tabular}{|c|c|c|c|c|}
\hline $\begin{array}{c}\text { Orientation } \\
\text { cities }\end{array}$ & East & South & West & North \\
\hline Changsha & $18.15 \%$ & $-5.18 \%$ & $8.69 \%$ & $-17.16 \%$ \\
\hline Shanghai & $22.88 \%$ & $3.20 \%$ & $17.27 \%$ & $-17.46 \%$ \\
\hline Nanjing & $1.40 \%$ & $-0.36 \%$ & $23.04 \%$ & $-19.18 \%$ \\
\hline Wuhan & $9.17 \%$ & $-9.17 \%$ & $1.70 \%$ & $-26.48 \%$ \\
\hline Chongqing & $11.10 \%$ & $-5.16 \%$ & $-2.63 \%$ & $-17.53 \%$ \\
\hline Chengdu & $25.71 \%$ & $10.89 \%$ & $26.89 \%$ & $0.87 \%$ \\
\hline
\end{tabular}

Heat loss in heating season

The heat losses of Case A-F in six cities in heating season are shown in Figure 3. 

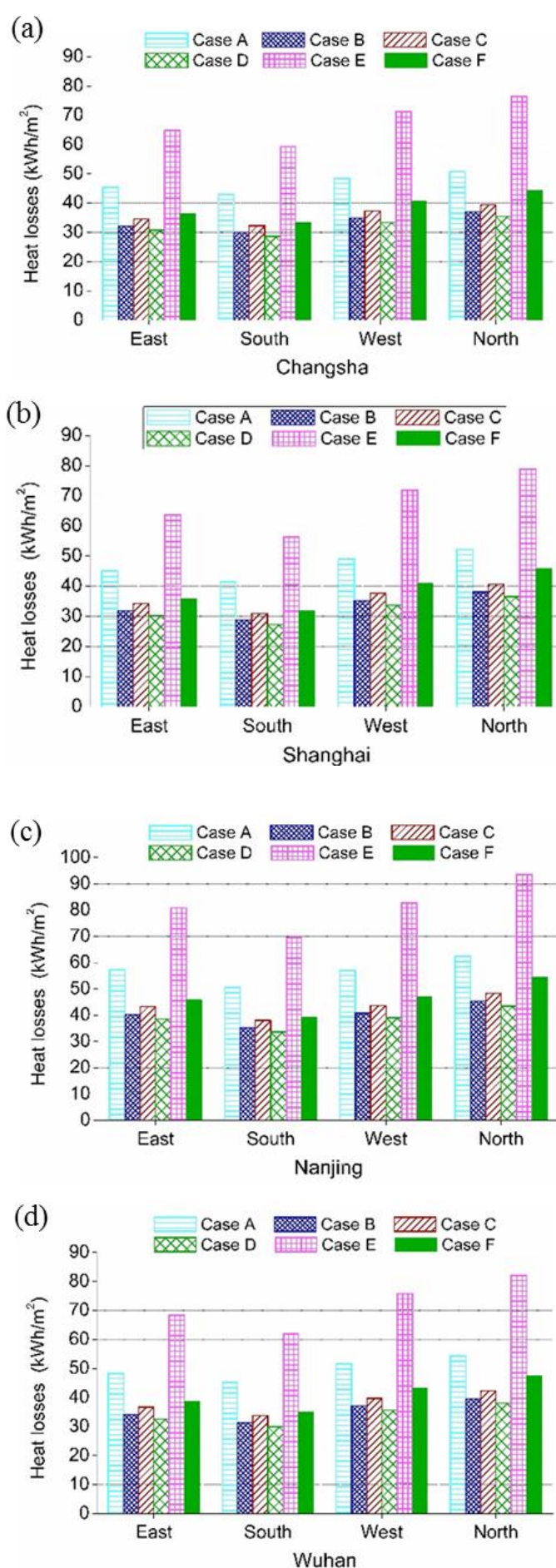

(e) 70 Case A 2 Case B DID Case C

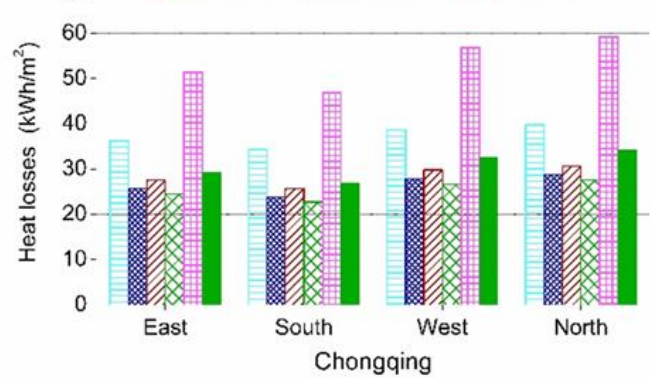

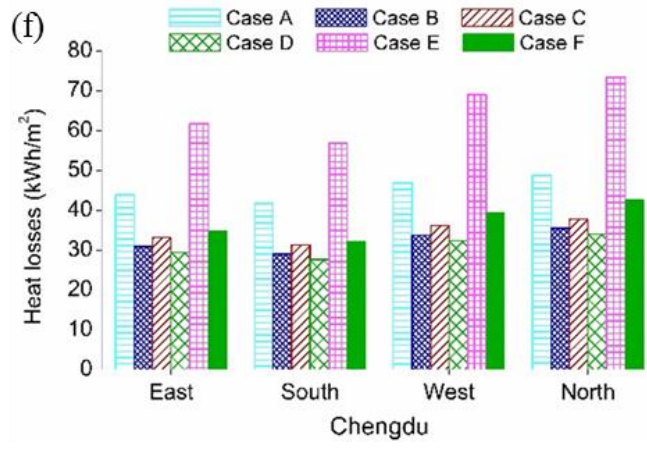

Figure 3: Heat loss through all fabrics in all orientations in heating season

Figure 3 shows that the heat loss of Case A and E are higher than the other fabrics, and that of the three thermally insulated walls (Case B, C and D) are very close. For different orientations, the heat loss in the north is maximal, the second is that in the west, and the minimum is that in the south. Heat loss of the DSF (Case F) compared with the most commonly used fabric (Case A) and the most thermally insulated fabric (Case D) in Tables 5 and 6. Compared to Case A, heat losses of the DSF in the east, south, west and north orientations are reduced at least by $26.33 \%, 30.19 \%, 20.11 \%$, and $14.08 \%$, respectively. Compared to the most thermally insulated fabric (Case D), the heat losses of the DSF in the east, south, west and north orientations are increased by $14.99 \%, 13.98 \%, 17.49 \%$, and $20.29 \%$, respectively. The comparisons indicate that the thermal and energy performance of DSF is better than the most commonly used fabric (Case A). It is also clear that the thermal and energy performance of the DSF is obviously better than that of the single glazing façade (Case E) with the reduction of at least $72 \%$ heat loss. Though in most of the cities, the thermal and energy performance of the DSF is not as good as the thermally insulated fabrics (Case B-D) in heating season, its performance is relatively close to the performance of the thermally insulated fabrics. In heating seasons, naturally ventilated DSF can make full use of the solar energy, which can not only decrease the heating load, but also improve indoor thermal comfort.

Table 5: Reduced heat loss (\%) of the DSF (Case F) compared to the most commonly used fabric (Case A) in heating season.

\begin{tabular}{|c|c|c|c|c|}
\hline $\begin{array}{c}\text { orientation } \\
\text { cities }\end{array}$ & East & South & West & North \\
\hline Changsha & $24.93 \%$ & $28.64 \%$ & $19.33 \%$ & $14.42 \%$ \\
\hline Shanghai & $26.33 \%$ & $30.19 \%$ & $20.11 \%$ & $14.08 \%$ \\
\hline Nanjing & $24.81 \%$ & $28.85 \%$ & $21.29 \%$ & $14.86 \%$ \\
\hline Wuhan & $25.46 \%$ & $28.80 \%$ & $19.67 \%$ & $14.22 \%$ \\
\hline Chongqing & $24.07 \%$ & $27.53 \%$ & $18.65 \%$ & $15.80 \%$ \\
\hline Chengdu & $25.69 \%$ & $29.16 \%$ & $19.04 \%$ & $14.58 \%$ \\
\hline
\end{tabular}

Table 6:Reduced heat loss (\%) of the DSF (Case F) compared to the most thermally insulated fabric (Case D) in heating season.

\begin{tabular}{|l|l|l|l|l|}
\hline orientation & East & South & West & North \\
\hline
\end{tabular}




\begin{tabular}{|c|c|c|c|c|}
\hline cities & & & & \\
\hline Changsha & $-15.64 \%$ & $-14.69 \%$ & $-17.98 \%$ & $-20.18 \%$ \\
\hline Shanghai & $-14.99 \%$ & $-13.98 \%$ & $-17.49 \%$ & $-20.29 \%$ \\
\hline Nanjing & $-16.01 \%$ & $-14.58 \%$ & $-17.20 \%$ & $-20.20 \%$ \\
\hline Wuhan & $-15.49 \%$ & $-14.78 \%$ & $-17.81 \%$ & $-20.27 \%$ \\
\hline Chongqing & $-16.49 \%$ & $-15.76 \%$ & $-18.41 \%$ & $-19.67 \%$ \\
\hline Chengdu & $-15.60 \%$ & $-14.63 \%$ & $-18.09 \%$ & $-20.09 \%$ \\
\hline
\end{tabular}

\section{Annual energy demand}

Annual energy of Case A-F in six cities in all orientations are shown in Figure 4.
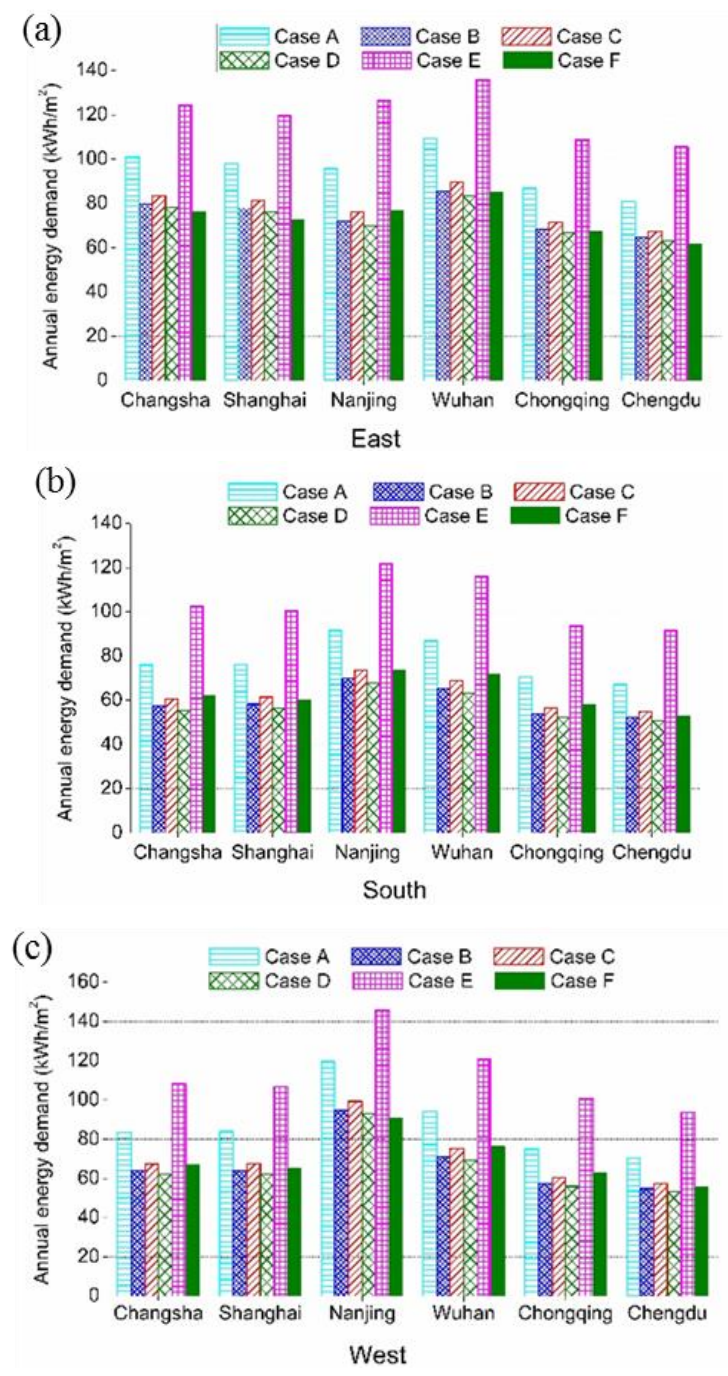

(d)

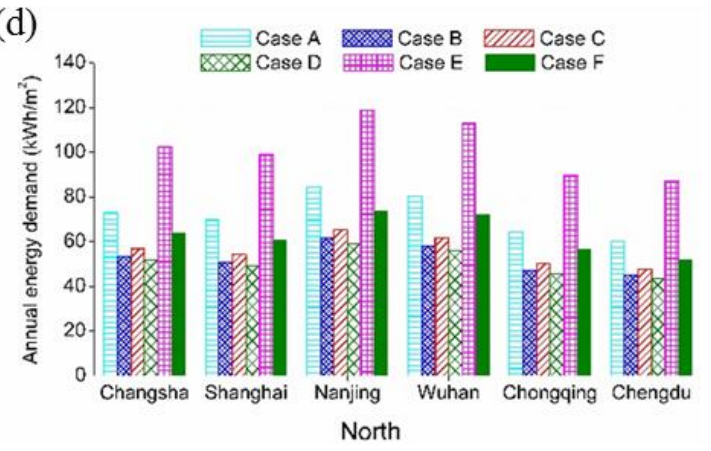

Figure 4:Annual energy demand of all fabrics in all orientations in six cities:(a) east, (b) south, (c) west, (d) north

Figure 4 shows the annual energy demand of each fabric in six cities. It shows that Case $\mathrm{E}$ and Case A have first and second maximum annual energy demand, which are much bigger than the other fabrics.

The reduced annual energy demand of the DSF (Case F) compared to the other fabrics are listed in Table 7.

Table 7:Reduced annual energy demand (\%) of the DSF (Case $F$ ) compared to the other fabrics in six cities.

(1:Changsha; 2:Shanghai; 3:Nanjing; 4:Wuhan; 5:Chongqing; 6:Chengdu)

\begin{tabular}{|c|c|c|c|c|c|}
\hline \multirow{7}{*}{ نे } & City & East & South & West & North \\
\hline & 1 & $31.9 \%$ & $22.5 \%$ & $24.9 \%$ & $14.0 \%$ \\
\hline & 2 & $34.7 \%$ & $27.0 \%$ & $28.5 \%$ & $14.8 \%$ \\
\hline & 3 & $24.9 \%$ & $24.7 \%$ & $31.5 \%$ & $14.5 \%$ \\
\hline & 4 & $28.9 \%$ & $21.2 \%$ & $23.7 \%$ & $11.8 \%$ \\
\hline & 5 & $29.0 \%$ & $21.6 \%$ & $19.7 \%$ & $14.2 \%$ \\
\hline & 6 & $31.2 \%$ & $26.2 \%$ & $26.2 \%$ & $16.0 \%$ \\
\hline
\end{tabular}

\begin{tabular}{|c|c|c|c|c|c|}
\hline \multirow{6}{*}{ 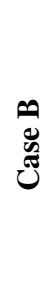 } & 1 & $4.5 \%$ & $-7.5 \%$ & $-4.8 \%$ & $-16.3 \%$ \\
\hline & 2 & $6.8 \%$ & $-3.1 \%$ & $-1.7 \%$ & $-16.5 \%$ \\
\hline & 3 & $-6.1 \%$ & $-5.2 \%$ & $4.5 \%$ & $-16.9 \%$ \\
\hline & 4 & $0.5 \%$ & $-9.1 \%$ & $-6.6 \%$ & $-19.4 \%$ \\
\hline & 5 & $1.6 \%$ & $-7.5 \%$ & $-8.4 \%$ & $-16.1 \%$ \\
\hline & 6 & $4.8 \%$ & $-1.9 \%$ & $-2.2 \%$ & $-13.4 \%$ \\
\hline \multirow{6}{*}{ 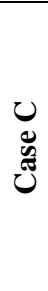 } & 1 & $9.2 \%$ & $-2.3 \%$ & $0.3 \%$ & $-11.1 \%$ \\
\hline & 2 & $11.6 \%$ & $2.1 \%$ & $3.5 \%$ & $-11.1 \%$ \\
\hline & 3 & $-0.8 \%$ & $-0.1 \%$ & $9.2 \%$ & $-11.5 \%$ \\
\hline & 4 & $5.3 \%$ & $-3.9 \%$ & $-1.5 \%$ & $-14.1 \%$ \\
\hline & 5 & $6.2 \%$ & $-2.5 \%$ & $-3.6 \%$ & $-10.1 \%$ \\
\hline & 6 & $9.5 \%$ & $3.1 \%$ & $2.9 \%$ & $-8.2 \%$ \\
\hline \multirow{6}{*}{ 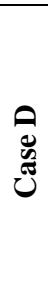 } & 1 & $2.0 \%$ & $-10.3 \%$ & $-7.5 \%$ & $-19.3 \%$ \\
\hline & 2 & $4.3 \%$ & $-5.9 \%$ & $-4.5 \%$ & $-19.6 \%$ \\
\hline & 3 & $-9.0 \%$ & $-7.9 \%$ & $2.2 \%$ & $-19.9 \%$ \\
\hline & 4 & $-2.0 \%$ & $-11.9 \%$ & $-9.4 \%$ & $-22.4 \%$ \\
\hline & 5 & $-0.9 \%$ & $-10.1 \%$ & $-10.9 \%$ & $-18.8 \%$ \\
\hline & 6 & $2.4 \%$ & $-4.6 \%$ & $-4.8 \%$ & $-16.3 \%$ \\
\hline \multirow{6}{*}{ 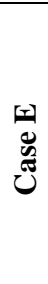 } & 1 & $62.6 \%$ & $65.3 \%$ & $61.3 \%$ & $60.3 \%$ \\
\hline & 2 & $64.0 \%$ & $67.2 \%$ & $63.6 \%$ & $62.3 \%$ \\
\hline & 3 & $64.7 \%$ & $65.8 \%$ & $60.4 \%$ & $60.9 \%$ \\
\hline & 4 & $59.8 \%$ & $61.5 \%$ & $58.3 \%$ & $57.1 \%$ \\
\hline & 5 & $61.3 \%$ & $61.3 \%$ & $60.6 \%$ & $59.0 \%$ \\
\hline & 6 & $71.0 \%$ & $72.5 \%$ & $67.7 \%$ & $67.4 \%$ \\
\hline
\end{tabular}

Compared to the most commonly used fabric (Case A), the annual energy demand of Case F can be reduced by at least $24 \%, 21 \%, 19 \%$, and $11 \%$ in east, south, west, and north orientations, respectively. In six cities, the annual energy demand of Case F can be reduced by at least $57 \%$ compared to Case E. The annual energy demand 
differences between Case $\mathrm{F}$ and the most thermally insulated fabric (Case D) are within $11 \%$ except in the north orientation of the six cities.

\section{Conclusion}

Energy performance is the most important basis to evaluate the applicability of the naturally ventilated DSF in HSCW zone in China. In this paper, an improved zonal model integrated with optical model and airflow model is used to hourly calculate the heat gain through the DSF and its annual energy demand. The model is validated by experiments. The model has good accuracy and fast computation speed for hourly calculation. The energy performance and applicability of naturally ventilated DSF with venetian blinds are evaluated by comparing the heat gains in summer, heat loss in winter and annual energy demand between the DSF and other five fabrics commonly used in HSCW zone.

To evaluate the annual energy performance of the naturally ventilated DSF in HSCW zone, the heat gain and loss in cooling and heating seasons, and annual energy demand in six typical cities in HSCW zone are calculated by the improved zonal model; that of the other five common used fabrics is also calculated. In cooling season, the heat gain of the DSF (Case F) is less than or close to that of the Case A-E in east, south and west orientation. Heat gain of the DSF compared to Case A in the east, south, west and north orientations reaches at least to $25.05 \%, 13.85 \%, 20.8 \%$, and $7.07 \%$. DSF has better energy efficiency than Case D in the east and west orientations; Case D has better energy efficiency than DSF in south and north orientation. In heating season, the energy performance of the DSF is not as good as that of Case B-D in most of the cities. However, the heat loss of the DSF is reduced by $14 \%$ and $72 \%$ compared to Case A and Case E, respectively.

Compared to the most commonly used fabric (Case A), the annual energy demand of the DSF is reduced by at least $24 \%, 21 \%, 19 \%$, and $11 \%$ in the east, south, west, and north orientations, respectively. The annual energy demand differences between the DSF and thermallyinsulated fabrics (Case B-D) are within 10\% except in the north orientation of the six cities.

The annual energy demand of the naturally ventilated DSF is slightly more than or close to the current thermally insulated fabrics in the HSCW zone. Considering the indoor lighting, visual comfort and some other advantages, the naturally ventilated DSF has good adaptability in HSCW zone in China.

\section{Acknowledgement}

This study was supported by the "13th Five-Year" National Key R\&D Project of China (Grant no. 2017YFC0702201)

\section{References}

Ahmed Hazem, Merzaka Ameghchouche, Cherif Bougriou (2015). A numerical analysis of the air ventilation management and assessment of the behavior of double skin façades. Energy and Buildings, 102, 225-236.

Alessandro Dama, Diego Angeli, Olena Kalyanova Larsen (2017). Naturally ventilated double-skin façade in modeling and experiments. Energy and Buildings, 144, 17-29.

Ali Ghaffarianhoseini, Amirhosein Ghaffarianhoseini, Umberto Berardi, John Tookey, Danny Hin Wa Li, Shahab Kariminia (2016). Exploring the advantages and challenges of double-skin façades (DSFs). Renewable and Sustainable Energy Reviews, 60, 1052-1065.

Alvaro de Gracia, Lidia Navarro, Albert Castell, et al. (2013). Numerical study on the thermal performance of a ventilated façade with PCM. Applied Thermal Engineering, 61, 372-380.

E. Sanchez, A. Rolando, R. Sant, L. Ayuso (2016). Influence of natural ventilation due to buoyancy and heat transfer in the energy efficiency of a double skin façade building. Energy for Sustainable Development, 33, 139-148.

Fallahi A., Haghighat F., Elsadi H. (2010). Energy performance assessment of double-skin façade with thermal mass. Energy and Buildings, 42, 1499-1509.

Fernando Varela, Francisco J. Rey, Eloy Velasco, Santiago Aroca (2012). The harmonic method: A new procedure to obtain wall periodic cross response factors. International Journal of Thermal Sciences, 58, 20-28.

Francesco Pomponi, Poorang A.E. Piroozfar, Ryan Southall, Philip Ashton, Eric. R.P. Farr (2016). Energy performance of Double-Skin Façades in temperate climates: A systematic review and metaanalysis. Renewable and Sustainable Energy Reviews, 54, 1525-1536.

GB 50736 (2012). Design code for heating ventilation and air conditioning of civil buildings (in Chinese).

G. Baldinelli (2009). Double skin façades for warm climate regions: Analysis of a solution with an integrated movable shading system. Building and Environment, 44, 1107-1118.

Hashemi N, Fayaz R, Sarshar M. (2010). Thermal behavior of a ventilated double skin façade in hot arid climate. Energy and Buildings, 42, 1823-1832.

Hossein Ghadamian, Mohammad Ghadimi, Mahdi Shakouri, et al. (2012). Analytical solution for energy modeling of double skin façades building. Energy and Buildings, 50, 158-165.

Jinqing Peng, Dragan C. Curcija, Lin Lu, Stephen E. Selkowitz, Hongxing Yang, Weilong Zhang (2016). Numerical investigation of the energy saving potential of a semi-transparent photovoltaic double-skin façade in a cool-summer Mediterranean climate. Applied Energy, 165, 345-356. 
Jinqing Peng, Lin Lu, Hongxing Yang (2013). An experimental study of the thermal performance of a novel photovoltaic double-skin façade in Hong Kong, Solar Energy, 97, 293-304.

L.G. Valladares-Rendón, Gerd Schmid, Shang-Lien Lo (2017). Review on energy savings by solar control techniques and optimal building orientation for the strategic placement of façade shading systems. Energy and Buildings, 140, 458-479.

Marta J.N. Oliveira Panão, Carolina A.P. Santos, Nuno M. Mateus, et al. (2016). Validation of a lumped RC model for thermal simulation of a double skin natural and mechanical ventilated test cell. Energy and Buildings, 121, 92-103.

María José Suárez, Cristina Sanjuan, Antonio José Gutiérrez, Jorge Pistono, Eduardo Blanco (2012). Energy evaluation of an horizontal open joint ventilated façade. Applied Thermal Engineering, 37, 302-313.

N. Hashemi, R. Fayaz, M. Sarshar (2010). Thermal behaviour of a ventilated double skin façade in hot arid climate. Energy and Buildings, 42, 1823-1832.

Wonjun Choi, Jaewan Joe, Younghoon Kwak, Jung-Ho Huh (2012). Operation and control strategies for multi-storey double skin façades during the heating season. Energy and Buildings, 49, 454-465.

Yangjin Wang, Youming Chen, Cong Li (2019). Airflow modeling based on zonal method for natural ventilated double skin façade with Venetian blinds. Energy and buildings, 191, 211-223.

Yanjin Wang, Youming Chen (2016). Modeling and calculation of solar gains through multi-glazing façades with specular reflection of venetian blind. Solar Energy, 130, 33-45.

Yanjin Wang, Youming Chen, Juan Zhou (2016). Dynamic modeling of the ventilated double skin façade in hot summer and cold winter zone in China. Building and Environment, 106, 365-377.

Yilin Li, Jo Darkwa, Georgios Kokogiannakis (2017). Heat transfer analysis of an integrated double skin façade and phase change material blind system, Building and Environment, 125, 111-121.

Yu-Min Kim, Ji-Hyun Lee, Sang-Min Kim, Sooyoung Kim (2011). Effects of double skin envelopes on natural ventilation and heating loads in office buildings. Energy and Buildings, 43, 2118-2126. 